Borzov S.O.

\title{
MATHEMATICAL MODELING OF WINDING SQUARE CARBOPLASTIC TUBES
}

\author{
Ukrainian State University of Chemical Technology, Dnipro, Ukraine
}

\begin{abstract}
The results of modeling thin-walled carbon fiber tubes of square section are presented. The task of the study is to determine and account for deviations during winding and rejection of such products. Traditionally, carbon fiber winding tubes are used for dimensionally stable structures, and circular tubes are used, which are easily wound, but have significant bending during bending. To eliminate this problem, it is proposed to use square carbon tubes. Such tubes have an advantage in gluing, since they include flat surfaces. Bending also decreases. To eliminate this problem, it is proposed to use square carbon tubes. Such tubes have an advantage in gluing, since they include flat surfaces. Bending also decreases. However, square tubes require a new approach when winding a carbon prepreg onto a square core. It is shown in the work that the main factor that leads to a spread in wall thicknesses is the alternation of straight sections and sections on the radii of rounding of a square mandrel. This cyclicity manifests itself with each revolution of the mandrel and leads to a significant increase in the pressing pressure at the corners of the square mandrel and the absence of such pressure in the straight sections of the square mandrel. There is no way to avoid this phenomenon on existing equipment. Therefore, a different approach was proposed. It consists in the fact that each manufactured element before entering the assembly phase is subjected to statistical analysis in order to determine the real moment of resistance to bending W. This analysis includes 4 steps. At the first stage, all four faces of each square tube are marked. At the second stage, the actual thickness of each wall is determined. At the third stage, the real moment of bending resistance is calculated for each of the four positions of the tube relative to the main axis of rotation. At the fourth stage, a map of the location of the tube inside the finished structure is created. This article provides the actual thickness of the carbon fiber tubes in the amount of 20 pieces. It is shown that such a method of taking into account thickness deviations will make it possible to find a reserve for reducing the deflection of the finished structure.
\end{abstract}

Keywords: carbon fiber, carbon plastic, prerpeg, carboplastic, tube.

DOI: $10.32434 / 2521-6406-2019-6-2-3-9$

\section{Statement of the problem}

The modern development of science requires ever more accurate measuring instruments. This task becomes even more difficult if it is additionally required to ensure other important factors, for example, the minimum mass. Measuring instruments are usually installed on supporting platforms, which should also have well-predicted spatial stability indicators. In addition, such devices and their platforms often operate in conditions of a significant temperature difference. All this requires fundamentally new solutions, primarily in the field of technology for the production of such structures, which are most often made from carbon fiber tubes.

This article is devoted to the study of technological features of the production of carbon fiber rod structures. Carbon fiber tubes are made by winding a crude prepreg onto a collapsible core (mandrel). The final assembly of the frame or truss is done by gluing. Seats for attaching research instruments are then attached to the finished rod structure. As a result, the accuracy of the positioning of the research instrument is the fifth or sixth stage of ensuring accuracy. Given that any composite structure has a natural variation in the output accuracy parameters, it becomes clear that research

(C) Borzov S.O., 2019 
should be continued.

Under the natural scatter of the output parameters in this paper, we mean the scatter of the wall thickness of the carbon fiber tubes, as well as the scatter of the actual bending elastic modulus. Thus, the real bending stiffness will be correlated with both geometric properties and material properties. Today it should be recognized that the reserve of properties of geometric sections seems to be higher than the reserve of properties of composite materials.

Thus, the idea was formed to replace round carbon fiber tubes with carbon fiber tubes of square cross section. However, the production technology and control of square tubes requires additional research. The prototypes of square tubes have been extensively tested, and these results are presented in this article.

\section{Analysis of recent research and publications}

Most modern high-precision platforms are made of carbon fiber [1-3].

This section of the analysis of publications is devoted to two important aspects. The first is the manufacture of carbon fiber tubes. The second is the control and further use of the tubes in the finished frame or truss.

An analysis of the available sources for the first aspect showed that the cross-sectional shape is a very important factor. Theoretical and practical work shows that a thin-walled square tube has a $50 \%$ less bending strain at the same profile height. A square thin-walled pipe with the same profile height has $25 \%$ more cross-sectional area. This has a positive effect on the strength and rigidity of the structure under tensile and compressive loads. In the case of square pipes, we have a jealous bonding surface on the side of all the elements. As a result, we get a well-controlled glue line. Adhesive bonding is better than bonding with mechanical elements [4]. These features give many advantages, however, they require taking into account the spread of technological parameters. Until recently, deviations of square tubes were only taken into account as a margin of safety or structural rigidity [5]. The article presents new results that make the production of square carbon pipes more advanced.

The second aspect of the manufacture of carbon fiber structures is the subsequent control. An example of non-destructive testing using the method of holographic interferometry is given in [3]. This is a good method for determining the imperfection of a composite element. However, this method does not allow to establish the actual values of the modulus of elasticity in bending.
The next important task is where and how to place the carbon fiber tube in the finished structure. To date, the design documentation does not regulate the sequence of the assembly process from existing tubes. But we know that each tube has its own unique modulus of elasticity. This suggests that the place of each tube in the finished structure must somehow correspond to its individual stiffness characteristics. Unfortunately, it was not possible to find works on this subject in the public domain.

\section{Research objective}

As an object of research, the manufacturing process of a carbon fiber square tube is considered. The manufacture is made by winding a carbon fiber impregnated with epoxy resin, which we will call prepreg on a square core (mandrel). Before starting production, it is necessary to develop a mathematical model of winding the prepreg on a square mandrel, since existing models are applicable only for round tubes.

It is believed that the process of winding carbon fiber will be carried out on the same equipment on which the traditional round tubes are wound. The only difference is that the core will be square, not round. The carbon filament winding angles will be the same for the two types of tubes.

An additional research factor is the need to control the external crimping of a square tube. This is very important, since on such surfaces the installation of connection elements between the platform and the research equipment takes place. If the outer surface will be of high quality, then the glue connection with the seat under the device will be durable and have good control of all sizes in space.

In addition to the absolute advantages of a square carbon fiber tube, relative advantages should also be taken into account. For example, the adequacy of the mathematical model of a round tube is considered higher than for a square tube. It should be noted that the spread of technological parameters for a round tube will be less than that of a square tube. This is due to a simpler cross-sectional shape in terms of winding processes. In addition, to date, not enough experience has been gained in operating detachable square cores, especially with prolonged use. These factors should be taken into account both in the mathematical model and in engineering practice.

Thus, the consideration of structural and technological factors in the manufacture of the core structure from carbon fiber tubes of square section is part of the overall process of obtaining a highquality and dimensionally stable structure.

The aim of the work is to develop a 
mathematical model for winding carbon fiber tubes of square cross section.

\section{Main material of the research}

A mathematical model for the manufacture of carbon fiber rods

As experience shows, the shape of the cross section is a factor that is very poorly appreciated. Theoretical and practical work shows that a thinwalled tube of square cross section has $50 \%$ less bending at a bend at the same profile height. A square thin-walled pipe with the same profile height has $25 \%$ more cross-sectional area [1]. Hubble telescope elements are made from such material [2]. This has a positive effect on the strength and rigidity of the structure under tensile and compressive loads. In the case of square tubes, we have a jealous gluing surface on the side of all elements. As a result, we get a well-controlled glue line. Adhesive bonding is better than bonding with mechanical elements $[3,4]$. These features give many advantages, however, they require taking into account the spread of technological parameters [4]. Until recently, deviations of square tubes were taken into account only as safety margins or structural stiffnesses. The paper presents new results that make the production of square carbon fiber tubes more perfect.

In the manufacture of carbon fiber tubes and of circular cross section:

$\mathrm{P}_{\mathrm{ro}}= \pm \sum_{\mathrm{i}=1}^{\mathrm{n}} \frac{\mathrm{N} \cos \alpha}{2 \pi \mathrm{R}}$.

In the manufacture of carbon fiber tubes of a square cross section:

$$
\mathrm{P}_{\mathrm{sq}}= \pm \sum_{\mathrm{i}=1}^{\mathrm{n}} \frac{\mathrm{N} \cos \alpha}{\pi\left(\mathrm{R}_{1}+\frac{\mathrm{R}_{1}}{\cos \alpha}\right)},
$$

where $\mathrm{P}_{\text {ro }}-$ the force acting on the core when winding a carbon thread on a round core; $\mathrm{P}_{\mathrm{sq}}-$ the force acting on the core when winding a carbon thread on a square core; $\mathrm{n}$ - the number of layers of winding; $\mathrm{N}-$ carbon thread tension; $\alpha-$ angle of winding carbon thread; $\mathrm{R}$ - radius of the cross section of the round core; $\mathrm{R}_{1}$ - rounding radius at the corners of a square core.

We calculate the difference in pressure on the round and square core. The initial parameters are indicated as formula:

$\mathrm{N}=10 \mathrm{kgs} ; \mathrm{a} \pm 45^{\circ} ; \mathrm{R}=0.015 \mathrm{~m} ; \mathrm{R}_{1}=0.005 \mathrm{~m}$.
The structure of the layers of the round and square tube is the same. The tube consists of 7 prepreg layers. Each layer has an estimated thickness of $0.13 \mathrm{~mm}$, with a filament thickness of $0.06 \mathrm{~mm}$ and an epoxy filler thickness of $0.07 \mathrm{~mm}$. 1st layer wound under. angle; then 2-6 layers are wound at an angle; the last 7 th layer is wound at an angle. The theoretical prepreg thickness after winding is $0.91 \mathrm{~mm}$. The theoretical prepreg thickness after crimping is $0.9 \mathrm{~mm}$.

The pressure on the core for one revolution of a round mandrel according to formulas (2) and (4) is:

$P_{\text {ro }}=\frac{10 \mathrm{~kg} \cdot \cos 45^{0}}{2 \cdot 3.14 \cdot 0.015 \mathrm{~m}}=743 \mathrm{~kg} / \mathrm{m}$.

The pressure on the core for one revolution of the square mandrel according to formulas (3) and (4) is:

$$
\mathrm{P}_{\mathrm{sq}}=\frac{10 \mathrm{~kg} \cdot \cos 45^{0}}{3.14\left(0.005+\frac{0.005}{\frac{\sqrt{2}}{2}}\right) \mathrm{m}}=1842 \mathrm{~kg} / \mathrm{m} \text {. }
$$

Comparing formulas (5) and (6), it becomes clear that at the corners of square tubes the pressure on the core is 2.5 times greater than when winding around a round core. Moreover, on flat sections of a square profile according to formula (4), this force is $\mathrm{kg} / \mathrm{m}$, and at the fillet corners $1842 \mathrm{~kg} / \mathrm{m}$. This is a very large unevenness.

\section{Mathematical modeling of prepreg thickness}

We see that at the corners of the square core the pressure rises sharply. This means that the epoxy matrix will actually be extruded from the prepreg. Thus, the real prepreg of the prepreg at the corners of the square core will be grassy with the thickness of the carbon thread. We write this feature through a change in the volume of the prepreg:

$V_{T}=\sum_{i=1}^{n} \frac{4 H-8 R_{1}+2 \pi R_{1}}{\cos \alpha} t_{p r p r}$,

where $\mathrm{V}_{\mathrm{T}}$ - theoretical prepreg volume when wound on a square core; $\mathrm{n}$ - number of winding layers; $\mathrm{H}$ - square tube profile height; $\alpha$ - angle of winding carbon thread; $\mathrm{R}_{1}$ - rounding radius at the corners of a square core; $t_{\mathrm{prpr}}$ - prepreg thickness.

The real volume of the prepreg, taking into account the fact that the epoxy matrix will be extruded at the corners of the square tube, is written 
as follows:

$$
\mathrm{V}_{\mathrm{A}}=\sum_{\mathrm{i}=1}^{\mathrm{n}} \frac{4 \mathrm{H} \cdot \mathrm{t}_{\mathrm{prpr}}-\left(8 \mathrm{R}_{1}+2 \pi \mathrm{R}_{1}\right) \cdot \mathrm{t}_{\mathrm{f}}}{\cos \alpha}
$$

where $\mathrm{V}_{\mathrm{A}}-$ actual prepreg volume when wound on a square core; $\mathrm{n}$ - number of winding layers; $\mathrm{H}-$ square tube profile height; $\alpha-$ angle of winding carbon thread; $\mathrm{R}_{1}$ - rounding radius at the corners of a square core; $\mathrm{t}_{\mathrm{prpr}}$ - prepreg thickness; $\mathrm{t}_{\mathrm{f}}-$ carbon fiber thickness.

Next, we determine the scatter of prepreg thicknesses for the first layer. The parameters of a square tube are as follows: $\mathrm{H}=30 \mathrm{~mm} ; \alpha= \pm 45^{\circ}$; $\mathrm{R}_{1}=5 \mathrm{~mm} ; \mathrm{t}_{\mathrm{prpr}}=0.13 \mathrm{~mm} ; \mathrm{t}_{\mathrm{f}}=0.06 \mathrm{~mm}$.

We write it like this:

$$
\begin{aligned}
& \frac{\mathrm{V}_{\mathrm{A}}}{\mathrm{V}_{\mathrm{T}}}=\frac{4 \mathrm{H} \cdot \mathrm{t}_{\mathrm{prpr}}-\left(8 \mathrm{R}_{1}+2 \pi \mathrm{R}_{1}\right) \cdot \mathrm{t}_{\mathrm{f}}}{\left(4 \mathrm{H}-8 \mathrm{R}_{1}+2 \pi \mathrm{R}_{1}\right) \cdot \mathrm{t}_{\mathrm{prpr}}}= \\
& =\frac{4 \cdot 30 \cdot 0,13-(8 \cdot 5+2 \cdot 3.14) \cdot 0.006}{(4 \cdot 30-8 \cdot 5+2 \cdot 3.14) \cdot 0.13}= \\
& =\frac{15.3223 \mathrm{~mm}^{3}}{11.2164 \mathrm{~mm}^{3}}=1.366 .
\end{aligned}
$$

The unevenness of the volume of the prepreg on the radii of rounded and flat areas during winding on a square core can exceed $30 \%$. If we recalculate the volume of the prepreg to its comrade, we get the following values:

$$
\begin{aligned}
& \mathrm{k}_{\mathrm{t}}=\frac{1_{\mathrm{sq}}}{1_{\mathrm{ro}}}=\frac{4 \mathrm{H}-8 \mathrm{R}_{1}}{4 \mathrm{H}-8 \mathrm{R}_{1}+2 \pi \mathrm{R}_{1}}= \\
& =\frac{4 \cdot 30-8 \cdot 5}{4 \cdot 30-8 \cdot 5+2 \cdot 3.14}=1.646 .
\end{aligned}
$$

It is seen that the spread of prepreg can exceed $60 \%$ for traditional production (Table 1).

To confirm the mathematical model, 20 carbon fiber tubes were manufactured. Then they were marked and the actual wall thicknesses $\mathrm{t} 1, \mathrm{t} 2, \mathrm{t} 3$, $\mathrm{t} 4$ were determined. The bending moment of resistance $\mathrm{W}$ is calculated for four positions that reflect the rotation of each bar relative to the main axis. In calculations of the moment of resistance to bending $\mathrm{W}$, this is expressed through a cyclic permutation of the thicknesses. Step 1. Without turning $-\mathrm{t} 1, \mathrm{t} 2, \mathrm{t} 3, \mathrm{t} 4$. Step 2. Rotate 90 degrees $-\mathrm{t} 4, \mathrm{t} 1, \mathrm{t} 2, \mathrm{t} 3$. Step 3. Rotate 180 degrees $\mathrm{t} 3, \mathrm{t} 4, \mathrm{t} 1, \mathrm{t} 2$. Step 4 . Turn 270 degrees $-\mathrm{t} 2, \mathrm{t} 3, \mathrm{t} 4, \mathrm{t} 1$. The calculation results are shown in table 1 and table 2 .

\begin{tabular}{|c|c|c|c|c|c|c|c|c|c|c|}
\hline \multirow{2}{*}{$\begin{array}{c}\text { Tube } \\
\text { number }\end{array}$} & \multicolumn{4}{|c|}{ Thickness, mm } & \multirow{2}{*}{$\mathrm{W}$} & \multicolumn{4}{|c|}{ Thickness, mm } & \multirow{2}{*}{ W } \\
\hline & $\mathrm{t} 1$ & $\mathrm{t} 2$ & $\mathrm{t} 3$ & $\mathrm{t} 4$ & & $\mathrm{t} 4$ & $\mathrm{t} 1$ & $\mathrm{t} 2$ & $\mathrm{t} 3$ & \\
\hline 1 & 1.05 & 1.00 & 0.95 & 1.15 & 810635.24 & 1.15 & 1.05 & 1 & 0.95 & 818813.08 \\
\hline 2 & 1.10 & 1.1 & 1.05 & 1.1 & 824294.49 & 1.1 & 1.1 & 1.1 & 1.05 & 827047.64 \\
\hline 3 & 1.20 & 0.95 & 1.2 & 1.1 & 840868.82 & 1.1 & 1.2 & 0.95 & 1.2 & 821501.77 \\
\hline 4 & 1.00 & 1.15 & 1.05 & 1 & 814717.96 & 1 & 1 & 1.15 & 1.05 & 820183.44 \\
\hline 5 & 1.10 & 1.1 & 0.95 & 0.95 & 812004.44 & 0.95 & 1.1 & 1.1 & 0.95 & 812004.44 \\
\hline 6 & 0.95 & 1 & 0.95 & 1.05 & 799837.34 & 1.05 & 0.95 & 1 & 0.95 & 807934.16 \\
\hline 7 & 1.25 & 1.05 & 1.2 & 1.15 & 849281.86 & 1.15 & 1.25 & 1.05 & 1.2 & 835310.72 \\
\hline 8 & 1.10 & 1.1 & 1 & 0.95 & 816087.16 & 0.95 & 1.1 & 1.1 & 1 & 813361.20 \\
\hline 9 & 1.05 & 1.05 & 0.95 & 1.1 & 810635.24 & 1.1 & 1.05 & 1.05 & 0.95 & 818813.08 \\
\hline 10 & 1.20 & 1.25 & 1.25 & 1.25 & 857751.85 & 1.25 & 1.2 & 1.25 & 1.25 & 860587.66 \\
\hline 11 & 0.95 & 1.15 & 1.15 & 0.95 & 817450.71 & 0.95 & 0.95 & 1.15 & 1.15 & 817450.71 \\
\hline 12 & 1.10 & 1.25 & 1.15 & 1.1 & 836720.91 & 1.1 & 1.1 & 1.25 & 1.15 & 842295.68 \\
\hline 13 & 1.05 & 1.05 & 1.05 & 1.1 & 818814.25 & 1.1 & 1.05 & 1.05 & 1.05 & 821553.79 \\
\hline 14 & 1.05 & 1.05 & 1.1 & 1.15 & 824294.49 & 1.15 & 1.05 & 1.05 & 1.1 & 827047.64 \\
\hline 15 & 1.10 & 1.1 & 1.05 & 1.1 & 824294.49 & 1.1 & 1.1 & 1.1 & 1.05 & 827047.64 \\
\hline 16 & 1.15 & 1 & 1.1 & 0.95 & 825648.65 & 0.95 & 1.15 & 1 & 1.1 & 809252.60 \\
\hline 17 & 1.15 & 1.05 & 0.95 & 1.25 & 822904.89 & 1.25 & 1.15 & 1.05 & 0.95 & 833944.68 \\
\hline 18 & 1.00 & 1.15 & 1.15 & 1 & 822924.14 & 1 & 1 & 1.15 & 1.15 & 822924.14 \\
\hline 19 & 1.25 & 0.95 & 1.1 & 1.1 & 836704.46 & 1.1 & 1.25 & 0.95 & 1.1 & 820145.01 \\
\hline 20 & 1.05 & 1.05 & 1.15 & 1.1 & 827047.64 & 1.1 & 1.05 & 1.05 & 1.15 & 824294.49 \\
\hline
\end{tabular}
The spread of the moment of resistance during bending is shown in table 3 .

Calculations of the moment of resistance to bending W. Step 1 and step 2

Table 1

Calculations of the moment of resistance to bending W. Step 1 and step 2 
Table 2

Calculations of the moment of resistance to bending W. Step 3 and step 4

\begin{tabular}{c|c|c|c|c|c|c|c|c|c|c}
\hline Tube & \multicolumn{4}{|c|}{ Thickness, $\mathrm{mm}$} & \multirow{2}{*}{$\mathrm{W}$} & \multicolumn{3}{|c|}{ Thickness, $\mathrm{mm}$} & \multirow{2}{*}{$\mathrm{W}$} \\
\cline { 2 - 6 } number & $\mathrm{t} 3$ & $\mathrm{t} 4$ & $\mathrm{t} 1$ & $\mathrm{t} 2$ & & $\mathrm{t}$ & $\mathrm{t} 3$ & $\mathrm{t} 4$ & $\mathrm{t} 1$ & \\
\hline 1 & 0.95 & 1.15 & 1.05 & 1 & 810635.24 & 1 & 0.95 & 1.15 & 1.05 & 818813.08 \\
\hline 2 & 1.05 & 1.1 & 1.1 & 1.1 & 824294.49 & 1.1 & 1.05 & 1.1 & 1.1 & 827047.64 \\
\hline 3 & 1.2 & 1.1 & 1.2 & 0.95 & 840868.82 & 0.95 & 1.2 & 1.1 & 1.2 & 821501.77 \\
\hline 4 & 1.05 & 1 & 1 & 1.15 & 814717.96 & 1.15 & 1.05 & 1 & 1 & 820183.44 \\
\hline 5 & 0.95 & 0.95 & 1.1 & 1.1 & 812004.44 & 1.1 & 0.95 & 0.95 & 1.1 & 812004.44 \\
\hline 6 & 0.95 & 1.05 & 0.95 & 1 & 799837.34 & 1 & 0.95 & 1.05 & 0.95 & 807934.16 \\
\hline 7 & 1.2 & 1.15 & 1.25 & 1.05 & 849281.86 & 1.05 & 1.2 & 1.15 & 1.25 & 835310.72 \\
\hline 8 & 1 & 0.95 & 1.1 & 1.1 & 816087.16 & 1.1 & 1 & 0.95 & 1.1 & 813361.20 \\
\hline 9 & 0.95 & 1.1 & 1.05 & 1.05 & 810635.24 & 1.05 & 0.95 & 1.1 & 1.05 & 818813.08 \\
\hline 10 & 1.25 & 1.25 & 1.2 & 1.25 & 857751.85 & 1.25 & 1.25 & 1.25 & 1.2 & 860587.66 \\
\hline 11 & 1.15 & 0.95 & 0.95 & 1.15 & 817450.71 & 1.15 & 1.15 & 0.95 & 0.95 & 817450.71 \\
\hline 12 & 1.15 & 1.1 & 1.1 & 1.25 & 836720.91 & 1.25 & 1.15 & 1.1 & 1.1 & 842295.68 \\
\hline 13 & 1.05 & 1.1 & 1.05 & 1.05 & 818814.25 & 1.05 & 1.05 & 1.1 & 1.05 & 821553.79 \\
\hline 14 & 1.1 & 1.15 & 1.05 & 1.05 & 824294.49 & 1.05 & 1.1 & 1.15 & 1.05 & 827047.64 \\
\hline 15 & 1.05 & 1.1 & 1.1 & 1.1 & 824294.49 & 1.1 & 1.05 & 1.1 & 1.1 & 827047.64 \\
\hline 16 & 1.1 & 0.95 & 1.15 & 1 & 825648.65 & 1 & 1.1 & 0.95 & 1.15 & 809252.60 \\
\hline 17 & 0.95 & 1.25 & 1.15 & 1.05 & 822904.89 & 1.05 & 0.95 & 1.25 & 1.15 & 833944.68 \\
\hline 18 & 1.15 & 1 & 1 & 1.15 & 822924.14 & 1.15 & 1.15 & 1 & 1 & 822924.14 \\
\hline 19 & 1.1 & 1.1 & 1.25 & 0.95 & 836704.46 & 0.95 & 1.1 & 1.1 & 1.25 & 820145.01 \\
\hline 20 & 1.15 & 1.1 & 1.05 & 1.05 & 827047.64 & 1.05 & 1.15 & 1.1 & 1.05 & 824294.49 \\
\hline
\end{tabular}

Table 3

Pipe number and reduction $\mathrm{W}$

\begin{tabular}{c|c}
\hline Tube number & $\mathrm{W}$ \\
\hline 6 & 818813.08 \\
\hline 5 & 827047.64 \\
\hline 8 & 840868.82 \\
\hline 11 & 820183.44 \\
\hline 1 & 812004.44 \\
\hline 9 & 807934.16 \\
\hline 4 & 849281.86 \\
\hline 13 & 816087.16 \\
\hline 18 & 818813.08 \\
\hline 16 & 860587.66 \\
\hline 2 & 817450.71 \\
\hline 14 & 842295.68 \\
\hline 15 & 821553.79 \\
\hline 20 & 827047.64 \\
\hline 17 & 827047.64 \\
\hline 19 & 825648.65 \\
\hline 3 & 833944.68 \\
\hline 12 & 822924.14 \\
\hline 7 & 836704.46 \\
\hline 10 & 827047.64 \\
\hline Max W & 860587.66 \\
\hline Min W & 807934.16 \\
\hline$\%$ & 6.12 \\
\hline & \\
\hline
\end{tabular}

\section{Conclusions}

1. Developed a mathematical model of winding on a square core.

2. It was found that the pressure of the prepreg at the radii of rounded square core significantly exceeds that in flat areas. This leads to extrusion of the epoxy matrix from the prepreg, which violates the quality of the square tube.

3. Using the developed model, it was found that the spread in the volume of the prepreg on the radii of rounded and on a flat section of the square core can exceed $30 \%$.

4. Using the developed model, it was found that the spread of the prepreg thicknesses on the radii of rounded and on the flat sections of the square core can exceed $60 \%$.

5. The proposed mathematical model can be used for a wide range of square tubes.

6 . The increase in bending moment was $6.12 \%$ without increasing the mass of the finished constructions.

\section{REFERENCES}

1. Сайm журнала «CompozitesWorld» [Электронный pecypc]. - Режим доступу: https://www.compositesworld.com/ articles/composites-stabilize-space-based-telescope. 
2. Пат. РФ 2417389, МПК G 02 В 23/00. Силовая ферма космического телескопа [Электронный ресурс] / А.М. Савицкий (РФ), М.Н. Сокольский (РФ), Л.Е. Левандовская (РФ) и др. - № 2529052; Заявл. 21.12.2012; Опубл. 27.09.2014. - Режим доступа: www.freepatent.ru/patents/2417389.

3. Пат. РФ 2503048, МПК G 02 В 23/16. Ферма силовая космического телескопа [Электронный ресурс] / А.Н. Шайда (РФ), В.И. Зацепин (РФ) и др. - № 2503048; Заявл. 26.06.2012; Опубл. 27.12.2013. - Режим доступа: www.freepatent.ru/patents/2503048

4. Воробьев Ю.А., Кушнаренко С.Г. Исследование статической прочности при растяжении-сжатии высокопрочных заклепочных соединений углепластика [Электронный ресурс] // Авіаційно-космічна техніка і технологія, 2003. - № 1. C.54-58. - Режим доступа: http://nbuv.gov.ua/UJRN/ aktit_2003_1_9.

5. Исследование терморазмеростабильности ферменных конструкций космических аппаратов / В.А. Коваленко, И.В. Малков, Г.В. Сыровой, Ю.В. Сохач // Вопросы проектирования и производства конструкций летательных аппаратов, 2011. - Вып. 2. - С.20-34. - Режим доступа: https://nbuv.gov.ua/UJRN/Pptvk_2011_2_4.

Received 13.11.2019

\section{МАТЕМАТИЧНЕ МОДЕЛЮВАННЯ НАМОТКИ КВАДРАТНИХ ВУГЛЕПЛАСТИКОВИХ ТРУБ}

\section{Борзов С.O.}

У даній роботі наводяться результати моделювання тонкостінних вуглепластикових трубок квадратного перетину. Завданням дослідження є визначення та облік відхилень під час намотування $і$ отвердження таких виробів. Традиційно намотувальні трубки з вуглепластику застосовуються для розміростабільних конструкцій, причому використовуються трубки круглого перетину, які легко намотуються, але мають значний прогин при вигині. Для усунення иієї проблеми запропоновано використовувати вуглепластикові трубки квадратного перетину. Такі трубки мають перевагу при склеюванні, так як включають плоскі поверхні. Також зменшується прогин при згині. Однак квадратні трубки вимагають нового підходу під час намотування вуглецевого препреги на квадратний сердечник. В роботі показано, що основним фактором, який призводить до розкиду товщини стінок, є чергування прямолінійних ділянок і ділянок на радіусах заокруглення квадратного дорна. Ця циклічність проявляється при кожному оберті дорна і призводить до суттєвого зростання тиску пресування на кутах квадратного дорна і відсутності такого тиску на прямолінійних ділянках квадратного дорна. Уникнути цього явища на існуючому обладнанні немає можливості. Тому був запропонований інший підхід. Він полягає в тому, що кожен виготовлений елемент перед надходженням на етап збірки піддається статистичному аналізу з метою визначення реального моменту опору на вигин $W$. Цей аналіз включає в себе 4 етапи. На першому етапі виконується маркування всіх чотирьох граней кожної квадратної трубки. На другому етапі виконується визначення фактичної товщини кожної стінки. На третьому етапі розраховується реальний момент опору на вигин для кожного $з$ чотирьох положень трубки щодо головної осі повороту. На четвертому етапі створюється карта розташування трубки всередині готової конструкиії. У даній статті наводяться фактичні товщини вуглепластикових трубок в кількості 20 штук.
Показано, що такий метод обліку відхилень товщини дозволить знайти резерв зменшення прогину готової конструкції.

Ключові слова: вуглецеве волокно, вуглепластик, препреги, намотування, вуглепластикова трубка.

\section{МАТЕМАТИЧЕСКОЕ МОДЕЛИРОВАНИЕ НАМОТКИ КВАДРАТНЫХ УГЛЕПЛАСТОВЫХ ТРУБ}

\section{Борзов С.A.}

В данной работе приводятся результаты моделирования тонкостенных углепластиковых трубок квадратного сечения. Заданием исследования является определение и учёт отклонений при намотке и отверджении таких изделий. Традиционно намоточные трубки из углепластика применяются для размеростабильных конструкций, причем используются трубки круглого сечения, которые легко наматываются, но имеют значительный прогиб при изгибе. Для устранения этой проблемы предложено использовать углепластиковые трубки квадратного сечения. Такие трубки имеют преимущество при склеивании, так как включают плоские поверхности. Также уменьшается прогиб при изгибе. Однако квадратные трубки требуют нового подхода при намотке углеродного препрега на квадратный сердечник. В работе показано, что основным фактором, который приводит к разбросу толщин стенок, является чередование прямолинейных участков и участков на радиусах скругления квадратного дорна. Эта цикличность проявляется при каждом обороте дорна и приводит к существенному возрастанию давления прессования на углах квадратного дорна и отсутствию такого давления на прямолинейных участках оснастки. Избежать данного явления на существующем оборудовании нет возможности. Поэтому был предложен другой подход. Он заключается в том, что каждый изготовленный элемент перед поступлением на сборку подвергается статистическому анализу с иелью определения реального момента сопротивления на изгиб $W$. Этот анализ включает $в$ себя 4 этапа. На первом этапе выполняется маркировка всех четырёх граней каждой квадратной трубки. На втором этапе выполняется определение фактической толщины каждой стенки. На третьем этапе рассчитывается реальный момент сопротивления на изгиб для каждого из четырёх положений трубки относительно главной оси поворота. На четвертом этапе создаётся карта расположения трубки внутри готовой конструкции. В данной статье приводятся фактические толщины углепластиковых трубок в количестве 20 штук. Показано, что такой метод учёта отклонений толщин позволит найти резерв уменьшения прогиба готовой конструкции.

Ключевые слова: углеродное волокно, углепластик, препрег, намотка, углепластиковая трубка. 


\section{MATHEMATICAL MODELING OF WINDING SQUARE} CARBOPLASTIC TUBES

\section{Borzov S.O.}

Ukrainian State University of Chemical Technology, Dnipro, Ukraine

The results of modeling thin-walled carbon fiber tubes of square section are presented. The task of the study is to determine and account for deviations during winding and rejection of such products. Traditionally, carbon fiber winding tubes are used for dimensionally stable structures, and circular tubes are used, which are easily wound, but have significant bending during bending. To eliminate this problem, it is proposed to use square carbon tubes. Such tubes have an advantage in gluing, since they include flat surfaces. Bending also decreases. To eliminate this problem, it is proposed to use square carbon tubes. Such tubes have an advantage in gluing, since they include flat surfaces. Bending also decreases. However, square tubes require a new approach when winding $a$ carbon prepreg onto a square core. It is shown in the work that the main factor that leads to a spread in wall thicknesses is the alternation of straight sections and sections on the radii of rounding of a square mandrel. This cyclicity manifests itself with each revolution of the mandrel and leads to a significant increase in the pressing pressure at the corners of the square mandrel and the absence of such pressure in the straight sections of the square mandrel. There is no way to avoid this phenomenon on existing equipment. Therefore, a different approach was proposed. It consists in the fact that each manufactured element before entering the assembly phase is subjected to statistical analysis in order to determine the real moment of resistance to bending $W$. This analysis includes 4 steps. At the first stage, all four faces of each square tube are marked. At the second stage, the actual thickness of each wall is determined. At the third stage, the real moment of bending resistance is calculated for each of the four positions of the tube relative to the main axis of rotation. At the fourth stage, a map of the location of the tube inside the finished structure is created. This article provides the actual thickness of the carbon fiber tubes in the amount of 20 pieces. It is shown that such a method of taking into account thickness deviations will make it possible to find a reserve for reducing the deflection of the finished structure.

Keywords: carbon fiber, carbon plastic, prerpeg, carboplastic, tube.

\section{REFERENCES}

1.Sayt zhurnala «CompozitesWorld» [Site of Journal «CompozitesWorld»]. Available at: https://www.compositesworld.com/ articles/composites-stabilize-space-based-telescope.

2. Savitsky A.M., Sokolsky M.N., Levandovskaya L.E. Silovaya ferma kosmicheskogo teleskopa [Space Telescope Power Farm]. Patent RF no. 2417389, G 02 B 23/00, 2012. (in Russian).

3. Shayda A.N., Zatsepin V.I. Ferma silovaya kosmicheskogo telescopa [The power farm of the space telescope]. Patent RF no. 2503048, G 02 B 23/16, 2013. (in Russian).

4. Vorobiov Y.A., Kushnarenko S.G. Issledovanie staticheskoy prochosti pri rastyazhenii-szhatii visokoprochnyih soedineniyi ugleplastika [Study of the static tensile-compression strength of high-strength riveted carbon fiber joints]. Aviatsiyno-kosmichna tehnika Itehnologiya [Aerospace and Space Engineering and Technology], 2003, no. 1, pp.54-58. (in Russian).

5. Kovalenko V.A., Malkov I.V., Syrovoy G.V., Sohach Y.V. Issledovanie termorazmerostabilnosti fermennyh konstruktsiy kosmicheskih apparatov [The study of thermal stability of truss structures of spacecraft]. Voprosy proektirovaniya I proizvodstva konstruktsiy letatelnyh apparatov [Issues of design and manufacture of aircraft structures], 2011. vol.2, pp.20-34. (in Russian). 